\title{
MACROECONOMIC FACTORS OF ECONOMIC GROWTH IN THE EUROPEAN UNION IN 2000-2016: A MULTIDIMENSIONAL ANALYSIS
}

\author{
Jacek Batóg \\ University of Szczecin, Szczecin, Poland \\ e-mail: jacek.batog@usz.edu.pl \\ ORCID:0000-0003-1413-7692
}

\author{
Barbara Batóg \\ University of Szczecin, Szczecin, Poland \\ e-mail: barbara.batog@usz.edu.pl
}

ORCID: 0000-0001-9236-7405

(C) 2019 Jacek Batóg, Barbara Batóg

This is an open access article distributed under the Creative Commons Attribution-NonCommercialNoDerivs license (http://creativecommons.org/licenses/by-nc-nd/3.0/)

DOI: 10.15611/eada.2019.3.01

JEL Classification: O47, C38

\begin{abstract}
The creation of an effective growth policy requires the identification of its key determinants. The study used one of the methods of multidimensional analysis - discriminant analysis. It is widely used on a microeconomic scale, especially in the area of forecasting bankruptcy of enterprises, but in the area of economic growth, it has not been used in practice so far. In addition to the main objective of identifying the most important economic growth factors of the European Union countries in 20002016, the impact of the crisis and accession to the EU was examined. The statistical data sources were the databases of Eurostat and the Conference Board (Total Economy Database). The results obtained allowed us to conclude that the rate of Gross Domestic Product growth in the EU countries was determined by consumption, investment, export and labour productivity, and in periods of economic slowdown also public debt. The enlargement of the EU resulted in an increase in the importance of export.
\end{abstract}

Keywords: economic growth, discriminant analysis, the European Union, economic crisis.

\section{Introduction}

Economic scholars have found that chosen macroeconomic variables are crucial determinants of economic growth. They have also been interested in identifying the key factors of distinct growth rates in different countries over time. Many researchers have pointed out that the inequality of growth in spatial and temporal terms is 
mostly the result of the diversity of sets of the considered phenomena that determine the dynamics of growth. These include economic and non-economic phenomena characterising a given country, especially those specific to a given stage of its development [Pritchett 2000, pp. 221-250]. Kosikowski also writes about the different course of growth and development processes in individual countries " ... there can be no uniform recipe (concept) for long-term growth and economic development for each country, since there is a variety of economic theories of growth and economic development, and individual countries differ from one another in many economic and social aspects" [Kosikowski 2004, p. 167].

The choice of the key factors of economic growth is of decisive importance in the construction of economic policy aimed at ensuring sustainable growth, especially during economic crises. In a growth theoretical framework, the neoclassical growth model explains the long-term growth rate of output based on the rate of population growth and the rate of technological progress [Ismail, Ahmed 2015, pp. 43-44]. New theories of economic growth indicate the following growth factors: the quality and supply of human capital, the level of social capital, the processes of technology diffusion, the learning and dissemination of knowledge, the choices made by household members regarding the level of fertility, and the amount of time spent on work or rest [Batóg 2010, p. 7]. Bosworth and Collins found that a very large portion of the cross-country variation in economic growth experiences over forty years, 1960-2000, can be related to the differences in the initial conditions (income level, life expectancy, population), the quality of governing institutions (law and order, absence of corruption, protection of property rights) and other factors (geographical location, predisposition to trade) [Bosworth, Collins 2003, p. 170].

The research conducted in the last 20 years indicated various sets of factors that influence economic growth, and showed that their influence depends not only on the set of examined objects but also on the period of analysis and research methods used. A broad discussion on the relationship between the factors and types of growth can be found in the work of Batóg [Batóg 2010, pp. 29-34].

The main aim of the study is to identify the most important economic growth factors of the European Union countries in 2000-2016 and to assess their stability. The research conducted so far has taken into account mainly the factors influencing long-term growth, such as the accession to the EU [Rapacki, Próchniak 2014] or the introduction of the common currency. In this study we focus on factors that are important in the short term, but we observe their effects over a long period, which allows us to notice a change in their impact on the growth of gross domestic product. This study is also distinguished by the research method used, which is discriminant analysis, very rarely used in macroeconomic analyses, especially in the area of economic growth. Its main applications are on a micro scale, mostly in the area of forecasting enterprise bankruptcy on the basis of economic and financial indicators and variables [Pociecha 2007] or macroeconomic factors [Agrawal, Maheshwari 2014]. 
The paper is organized as follows. In the next part, selected current research focused on macroeconomic factors related to the competitiveness, economic situation and economic potential based on discriminant analysis are presented. The third part presents some methodological approaches used in analyses of economic growth and their limitations, as well as a short description of the idea of multidimensional analysis. The fourth section consists in data characteristics and a discussion on the results and findings of the study. The final section presents the concluding remarks and potential directions of future research.

\section{Current research review}

Recent decades have seen an explosion of empirical research on economic growth and its determinants, but still many of the central issues remain unresolved. Among them we can point out the lack of consensus about the relative contributions of capital accumulation and improvements in Total Factor Productivity (TFP) in accounting for spatial and time differences in growth, as well as ambiguities about the role of increased education or the importance of economic policy. The results from the many studies frequently reach the opposite conclusions [Bosworth, Collins 2003].

Although studies on the identification of the factors determining the macroeconomic situation of countries and their economic growth dynamics are very wide, only a few of them use the method of discriminant analysis (see: [Temple 1999; Ahn, Hemmings 2000; Siedlecki 2000; Czerwiński 2002; Piasecki 2003; Durlauf, Johnson, Temple 2005; Woźniak 2004; Borys 2005; Próchniak 2005; Zrozumieć wzrost gospodarczy... 2005; Budner 2006; Piontek 2006; Batóg 2007, 2010; Rapacki (ed.) 2009]). In the paper [Choudhury, Naidu 2009] this method was used to assess the possibility of Turkey's accession to the European Union, although the economic profile for Turkey and reference countries was created and evaluated using only four economic factors: Gross Domestic Product (GDP) growth rate, current account balance ( $\%$ of GDP), inflation rate and interest rate. The authors showed that Turkey does not have a similar economic status nor, in the near future, the prospect of becoming a member of the EU on the basis of its economic profile in 2002-2006. A similar study was carried out in a study by Trpkova, Tevdovski [2010], in which the economic potential of 48 countries in terms of their membership and accession to the European Union was studied by means of a multivariate discriminant analysis. The set of discriminant variables included economic (Foreign Direct Investment (FDI), GDP growth rate, GDP per capita, inflation), demographic (population) and other variables (mobile cellular subscriptions, surface area). The results indicated that mobile cellular subscriptions, FDI and size of the gross domestic product mostly contribute to the discrimination between groups characterized by different rates of growth. The classification using discriminant analysis also made it possible to compare the macroeconomic situation of eurozone countries against the 33 
selected highly developed countries [Maniatis 2013]. The author used the following variables: the national debt of the country as a percentage of the GDP, the budget deficit as a percentage of the GDP, the annual inflation rate, the balance of payment as a percentage of the GDP, the unemployment rate as a percentage of the active population and the OECD composite leading indicator. The study concludes that despite the budget and debt crisis hitting some major and minor eurozone members, the "real" economy of the eurozone still occupies the first-class place in the global economy. Fernandes [2013] carried out an interesting analysis of the socio-economic factors differentiating EU countries, indicating at the same time the importance of the quality of infrastructure and the degree of Information and Communication Technologies (ICT) adoption. The strong influence of ICT on economic and human development was also proved in Cortés, Navarro [2011]. It is worth noting that the discriminant analysis was preceded by a cluster analysis with the help of which three sets of main factors differentiating the analysed countries were identified: governance (consumer confidence, e-government availability, knowledge activity, high skills, real GDP growth, Research and Development (R\&D) expenditure growth), cohesiveness (public connectivity, unemployment, regional inequalities, income inequalities) and entrepreneurship (participation in training, expenditure on tertiary education, trust, job mobility).

\section{Research method}

Understanding the characteristics and determinants of economic growth requires an empirical framework that can be applied to large groups of countries over a relatively long period. The fulfilment of this condition does not guarantee adequate results either, as differences in the assessment of the weight of individual growth determinants also result from differences in the approaches and methods used to identify and measure them. Two main approaches - growth accounts and growth regressions - provide a framework in a way that is particularly informative because they enable researchers to explore the channels through which various determinants influence growth [Bosworth, Collins 2003], although it should be noted that these two empirical approaches are also labelled by some researchers as irrelevant to policymaking [Bosworth, Collins 2003, p. 113]. Most econometric studies related to economic growth prefer the popular econometric techniques employing classical regression techniques, while methods of multivariate statistics and non-linear regressions occupy a minor place. Frequently used methods used to identify important growth factors include: reasonable extreme-bounds [Doppelhoffer 2000], gravity models and Bayesian averaging of classical estimates [Doppelhofer et al. 2000]. Some sources underline that standard econometric methods like for instance the fixed-effects model used for panel data often leads to the elimination of important information contained in the cross-sectional data. We can find also a critique of the chosen models of stochastic processes, denoting that determining the first differences 
of the examined variables strengthens the effects of measurement errors and increases the sensitivity of the obtained results to inaccurately defined time links between the measure of economic growth and its determinants [Barro 1996, p. 24]. Classical econometric tools cannot avoid either such limitations like the model selection and robustness that have been identified as a major weakness of crosscountry growth research.

Multivariate data used in examining economic growth call for multivariate techniques, which at the cost of losing information and detail allow for perceiving the data structure better. If we consider all the above indications, it seems reasonable to choose the discriminant analysis as an unbiased investigation technique in growth research [Maniatis 2013]. Such an approach was also suggested by Durlauf, Johnson and Temple, who present the review of growth econometrics and indicate at the end that multidimensional analyses (classification and regression trees) are appropriate for economic growth examination [Durlauf et al. 2005, p. 651]. Empirical applications of discriminant analysis in microscale are mostly related to the prediction of companies' bankruptcy. We can also find some other adoption of this method, e.g. in the assessment of financial situation of firms [Batóg, Wawrzyniak 1997] or in the identification of determinants of the rate of return [Batóg, Batóg 2012].

The discriminant analysis was proposed for the first time by Fisher [1936]. Its main assumptions are: data represent a sample from a multivariate normal distribution, the variance/covariance matrices of variables are homogeneous across groups and variables that are used to discriminate between groups are not completely redundant. The multiple discriminant analysis applied in the current study deals with multiple dependent variables - because more than two groups are analyzed. The aim of this method is to examine whether a set of $p$ variables $\left(X_{1}, \ldots\right.$, $\left.X_{p}\right)$ is capable of distinguishing (discriminating) among $g$ groups. The main result of multiple discriminant analysis are discriminant functions. These functions are the linear combinations of the discriminant variables on the basis of which the groups are maximally distinguished [Tacq 2007]. This means that the coefficients of linear combinations $(\beta)$ satisfy the conditions of maximization of the ratio of between group variance $(B)$ to within group variance $(W)$ [Panek 2009; McLachlan 2004]:

$$
\hat{\beta}=W^{-1} B .
$$

The formula for canonical discriminant functions is given by Eq. 2 .

$$
D_{k j}=\beta_{0 j}+\beta_{1 j} x_{1 k}+\ldots+\beta_{p j} x_{p k},
$$

where: $k=1, \ldots, n ; j=1, \ldots, r ; i=1, \ldots, p ; n$-number of observations; $r$-number of discriminant functions; $p$ - number of discriminant variables; $D_{k j}-$ value of $j$ th canonical discriminant function for observation $k ; x_{i k}$ - value of $i$-th discriminant variable for observation $k ; \beta_{i j}$ - parameters of canonical discriminant function. 
The number of discriminant function $(r)$ is equal to $\min (g-1, p)$.

In order to find the parameters of the canonical discriminant function, the canonical correlation analysis is applied. The problem is limited to solving the system of equations:

$$
\left(W^{-1} B-\lambda I\right) \hat{\beta}=0,
$$

where $\lambda$ is called an eigenvalue, by using the characteristic equation:

$$
\operatorname{det}\left(W^{-1} B-\lambda I\right) \text {. }
$$

This allows to calculate a maximum value for $\lambda$ and find the respective vector $\hat{\beta}$.

When the successive functions and canonical roots are determined (the term root refers to the eigenvalues that are associated with the respective canonical function), it is possible to test significance for roots by means of the $\chi^{2}$ test. In the first step the test for all roots is conducted. Then the highest root is removed and the significance of the remaining roots is tested. These procedure is continued to the last root. We can find several modifications of standard discriminant analysis that enable to improve the quality of classification. Some of them are based on transformations of a priori or a posteriori probabilities, while some are related to the direct incorporation of spatial relations in the discriminant function [Batóg 2009].

The quality of the obtained discriminant function is examined by means of Wilks' Lambda statistic. This statistic is computed for the whole model and also for the models without a given variable and with only one variable (partial Wilks' Lambda statistic). Value 0 of Wilks' Lambda means perfect discrimination and value 1 means no discrimination, and $\mathrm{F}$ statistic is used for testing the significance of the whole model.

For every group the classification function is computed as a linear combination of discriminant variables [Johnson, Wichern 2007]. The given observation is classified into known (a priori) group for which the value of the classification function is the highest. The accuracy of discrimination interpreted as the share of properly classified observations in the total number of observations can be evaluated by the formula:

$$
\text { Accuracy of classsification }=\frac{n_{0}}{n} \cdot 100 \%,
$$

where: $n$ - number of observations; $n_{0}$ - number of properly classified observations.

\section{Data structure and empirical results}

The analysis of the most important determinants of economic growth in the 27 European Union countries (due to numerous data gaps, Cyprus was not included 
Table 1. Standardized coefficients of discriminant functions and results of the $\chi^{2}$ test for subsequent discriminant functions (2014)

\begin{tabular}{|c|c|c|c|c|}
\hline \multirow{2}{*}{ Variable } & \multicolumn{4}{|c|}{ Standardized coefficients of discriminant functions } \\
\hline & function 1 & function 2 & \multicolumn{2}{|c|}{ function 3} \\
\hline $\mathrm{X}_{1}$ & -0.633 & -0.633 & \multicolumn{2}{|c|}{0.184} \\
\hline $\mathrm{X}_{2}$ & -0.507 & -0.507 & \multicolumn{2}{|c|}{-0.006} \\
\hline $\mathrm{X}_{3}$ & 0.274 & 0.274 & \multicolumn{2}{|c|}{0.066} \\
\hline $\mathrm{X}_{4}$ & -0.375 & -0.375 & \multicolumn{2}{|c|}{-0.340} \\
\hline $\mathrm{X}_{5}$ & 0.873 & 0.873 & \multicolumn{2}{|c|}{-0.063} \\
\hline $\mathrm{X}_{6}$ & 0.260 & 0.260 & \multicolumn{2}{|c|}{-0.456} \\
\hline $\mathrm{X}_{7}$ & 0.594 & 0.594 & \multicolumn{2}{|c|}{-0.650} \\
\hline $\mathrm{X}_{8}$ & -0.672 & -0.672 & \multicolumn{2}{|c|}{-0.819} \\
\hline $\mathrm{X}_{9}$ & 0.073 & 0.073 & \multicolumn{2}{|c|}{0.573} \\
\hline $\mathrm{X}_{10}$ & 0.081 & 0.081 & \multicolumn{2}{|c|}{0.035} \\
\hline $\mathrm{X}_{11}$ & 0.235 & 0.235 & \multicolumn{2}{|c|}{0.611} \\
\hline $\mathrm{X}_{12}$ & 0.237 & 0.237 & \multicolumn{2}{|c|}{-0.959} \\
\hline Eigenvalues & 3.061 & 3.061 & \multicolumn{2}{|c|}{1.073} \\
\hline Cumulative percent & 0.897 & 0.897 & \multicolumn{2}{|c|}{1.000} \\
\hline \multicolumn{5}{|c|}{ The $\chi^{2}$ test for subsequent discriminant functions } \\
\hline $\begin{array}{c}\text { Number } \\
\text { of removed roots }\end{array}$ & Eigenvalue & $\chi^{2}$ & $\begin{array}{c}\text { Degrees } \\
\text { of freedom }\end{array}$ & $p$ \\
\hline 0 & 6.255 & 74.014 & 36 & 0.000 \\
\hline 1 & 3.061 & 38.343 & 22 & 0.017 \\
\hline 2 & 1.073 & 13.118 & 10 & 0.217 \\
\hline
\end{tabular}

Source: own calculations.

in the set of examined objects) in 2000-2016 was carried out with the use of the following 12 variables characterizing various economic factors and the intensity of migration:

1. $X_{1}$ - growth of government consolidated gross debt (as a percentage of GDP),

2. $X_{2}$ - employment rate,

3. $\mathrm{X}_{3}$ - growth of export of goods and services (current prices, PPP),

4. $\mathrm{X}_{4}$ - growth of gross capital formation (current prices, PPP),

5. $\mathrm{X}_{5}$ - share of ICT capital compensation in GDP,

6. $\mathrm{X}_{6}$ - growth of labour quality (change in the education level),

7. $\mathrm{X}_{7}$ - growth of total labour cost of hour worked (US\$),

8. $\mathrm{X}_{8}$ - growth of final consumption expenditure (current prices, PPP),

9. $X_{9}-$ net migration/population,

10. $\mathrm{X}_{10}-$ growth of TFP, 


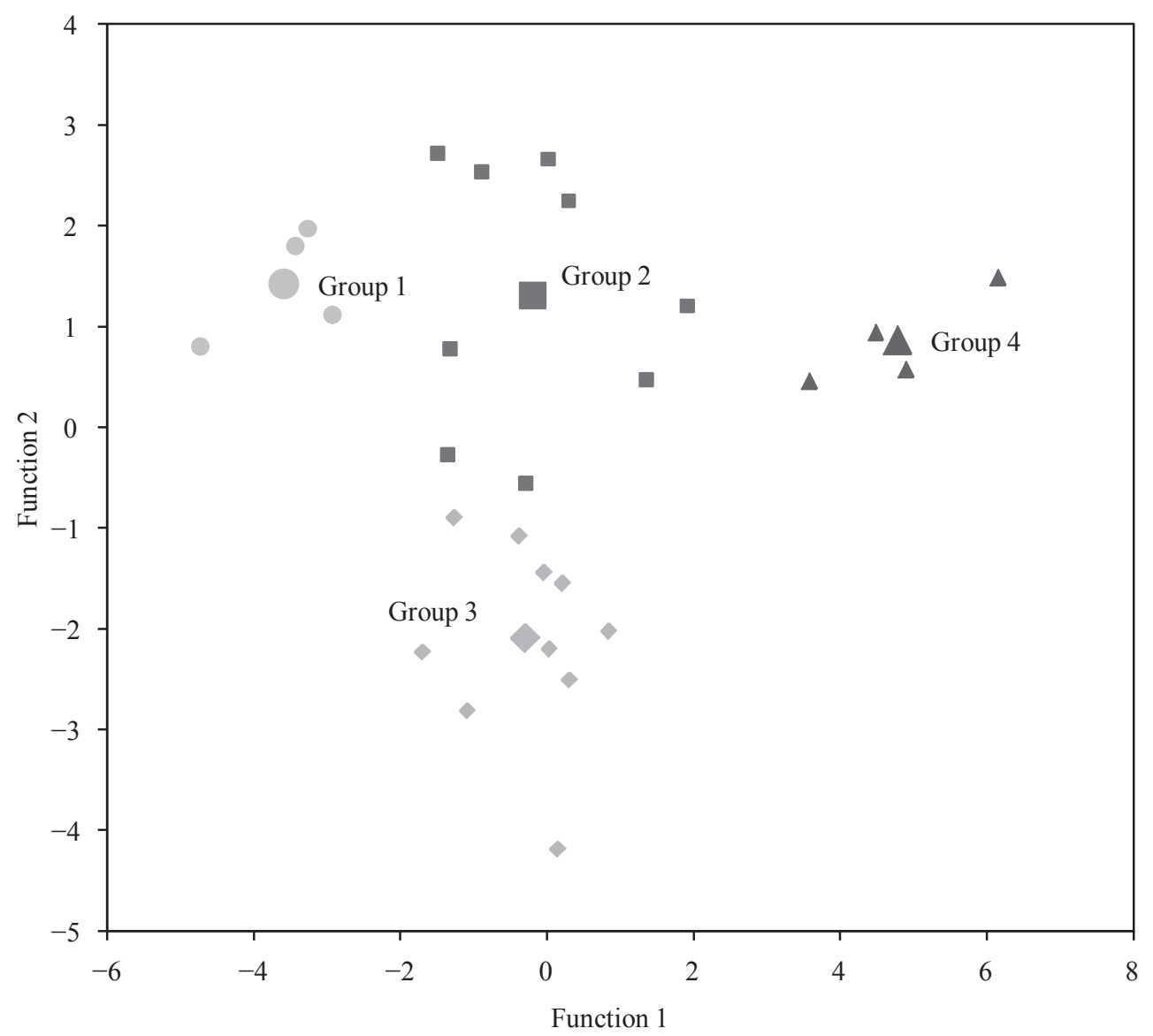

Fig. 1. Canonical values in discriminant space in 2014

Source: own calculations.

11. $\mathrm{X}_{11}$ - labour productivity per hour worked (in 2017 US\$, converted to 2016 price level with updated 2011 PPPs),

12. $\mathrm{X}_{12}$ - total general government expenditure (as a percentage of GDP).

All the variables were expressed in relative terms by means of changes or as measures of the intensity of specific phenomenon. The role of grouping variable was played by the GDP growth rate expressed in current prices in terms of PPP. Assignment to four categories of GDP dynamics (group 1 - the lowest GDP growth, group 2 - lower than average GDP growth, group 3 - higher than average GDP growth, group 4 - the strongest GDP growth) was determined on the basis of the three-means method. The sources of data were the following databases: Eurostat and The Conference Board (Total Economy Database, March 2018). 
The discriminant analysis was applied in every year separately. The results of the estimation obtained for the selected year 2014 are presented in Table 1 and Figure 1. Table 1 contains standardized coefficients of the canonical discriminant functions and the results of the $\chi^{2}$ test for subsequent discriminant functions, and Figure 1 presents the canonical values in discriminant space.

We can observe that the two first discriminant functions possess strong discriminant power - they explain $89.7 \%$ of the variation of economic growth within EU countries. According to the first canonical discriminant function, the most important factors of economic growth in 2014 were: growth of export of goods and services, growth of gross capital formation, share of ICT capital compensation in GDP, growth of total labour cost of hour worked, net migration/population, labour productivity per hour worked and total general government expenditure.

The concentration of objects around their centroids indicates strong discrimination of countries belonging to group 1 (slowest economic growth) and group 4 (strongest economic growth) and the relatively low homogeneity of countries belonging to group 2 and group 3 (with growth dynamics close to the EU average).

Very similar results were obtained in the remaining years. The membership of individual countries in four groups (1-4) with diversified GDP dynamics is presented in Table 2 (for the old EU members) and Table 3 (for the new EU members).

Table 2. Assignment to GDP growth groups (EU-15)

\begin{tabular}{|c|c|c|c|c|c|c|c|c|c|c|c|c|c|c|c|c|c|}
\hline Country & ஓ্ণ & ¿্口 & ఠ̊ & ֻ̊ণ & $\underset{\sim}{\stackrel{+}{8}}$ & $\stackrel{\overbrace{}}{\tilde{\delta}}$ & ঠి & $\hat{\text { d }}$ & $\stackrel{\infty}{\stackrel{\overbrace{}}{\delta}}$ & ஓి & $\stackrel{\circ}{\stackrel{\circ}{\sim}}$ & $\underset{\bar{D}}{\overline{0}}$ & $\frac{\sim}{\stackrel{\sim}{(}}$ & $\stackrel{m}{\stackrel{n}{\sim}}$ & $\stackrel{\searrow}{\stackrel{\sim}{\circ}}$ & $\stackrel{n}{\stackrel{n}{\sim}}$ & $\begin{array}{l}0 \\
\stackrel{0}{0}\end{array}$ \\
\hline Austria & 2 & 1 & 2 & 2 & 3 & 2 & 1 & 1 & 2 & 4 & 3 & 3 & 4 & 3 & 2 & 3 & 3 \\
\hline Belgium & 3 & 1 & 2 & 1 & 1 & 1 & 1 & 1 & 2 & 4 & 4 & 2 & 3 & 2 & 2 & 2 & 2 \\
\hline Denmark & 2 & 2 & 1 & 1 & 3 & 1 & 2 & 1 & 3 & 2 & 3 & 2 & 2 & 3 & 2 & 2 & 1 \\
\hline Finland & 3 & 2 & 1 & 1 & 3 & 1 & 1 & 3 & 3 & 3 & 2 & 3 & 2 & 2 & 1 & 2 & 2 \\
\hline France & 3 & 3 & 1 & 1 & 1 & 2 & 1 & 2 & 1 & 4 & 4 & 2 & 2 & 4 & 2 & 1 & 1 \\
\hline Greece & 1 & 3 & 3 & 3 & 2 & 1 & 3 & 1 & 2 & 3 & 1 & 1 & 1 & 2 & 2 & 1 & 1 \\
\hline Spain & 3 & 3 & 3 & 2 & 2 & 3 & 3 & 3 & 2 & 3 & 1 & 1 & 1 & 1 & 2 & 3 & 3 \\
\hline Netherlands & 3 & 2 & 1 & 1 & 2 & 2 & 2 & 2 & 2 & 2 & 2 & 2 & 2 & 3 & 1 & 2 & 1 \\
\hline Ireland & 4 & 4 & 4 & 2 & 4 & 3 & 3 & 3 & 2 & 2 & 3 & 2 & 3 & 3 & 4 & 4 & 3 \\
\hline Luxembourg & 4 & 2 & 2 & 2 & 3 & 3 & 4 & 3 & 2 & 2 & 3 & 4 & 2 & 4 & 4 & 3 & 1 \\
\hline Germany & 1 & 1 & 1 & 1 & 1 & 1 & 1 & 2 & 2 & 3 & 3 & 3 & 3 & 3 & 3 & 3 & 3 \\
\hline Portugal & 2 & 2 & 2 & 1 & 1 & 3 & 2 & 1 & 1 & 4 & 2 & 1 & 1 & 2 & 2 & 2 & 2 \\
\hline Sweden & 3 & 1 & 1 & 2 & 3 & 1 & 1 & 3 & 1 & 2 & 2 & 3 & 3 & 2 & 2 & 3 & 2 \\
\hline Great Britain & 3 & 2 & 2 & 2 & 2 & 1 & 1 & 1 & 1 & 2 & 3 & 2 & 3 & 3 & 3 & 3 & 2 \\
\hline Italy & 1 & 1 & 1 & 1 & 1 & 2 & 1 & 2 & 2 & 4 & 3 & 2 & 1 & 1 & 1 & 1 & 3 \\
\hline
\end{tabular}

Source: own calculations. 
Table 3. Assignment to GDP growth groups (EU-12)

\begin{tabular}{|c|c|c|c|c|c|c|c|c|c|c|c|c|c|c|c|c|c|}
\hline Country & $\underset{\sim}{\stackrel{丶}{\circ}}$ & $\underset{\sim}{\stackrel{8}{0}}$ & $\underset{\sim}{\tilde{\delta}}$ & $\stackrel{\text { }}{\stackrel{0}{8}}$ & $\underset{\sim}{\stackrel{+}{8}}$ & $\stackrel{n}{8}$ & $\underset{\sim}{\stackrel{丶}{~}}$ & $\stackrel{i}{8}$ & $\stackrel{\infty}{\stackrel{\infty}{\circ}}$ & ஓ् & $\stackrel{\circ}{\stackrel{\circ}{\circ}}$ & $\vec{\nabla}$ & $\stackrel{\sim}{\stackrel{\sim}{\sim}}$ & $\stackrel{m}{\stackrel{N}{\sim}}$ & $\underset{\sim}{\stackrel{\Delta}{\sim}}$ & $\stackrel{n}{\stackrel{2}{\sim}}$ & $\stackrel{\circ}{\stackrel{0}{0}}$ \\
\hline Bulgaria & 4 & 3 & 4 & 3 & 3 & 4 & 2 & 4 & 4 & 3 & 3 & 2 & 4 & 1 & 3 & 2 & 2 \\
\hline Croatia & 2 & 2 & 3 & 3 & 2 & 2 & 4 & 3 & 3 & 2 & 1 & 2 & 2 & 2 & 1 & 2 & 3 \\
\hline Czech Republic & 2 & 3 & 1 & 3 & 3 & 2 & 2 & 3 & 3 & 4 & 2 & 2 & 2 & 3 & 4 & 2 & 1 \\
\hline Estonia & 4 & 3 & 4 & 4 & 4 & 4 & 4 & 4 & 1 & 1 & 3 & 4 & 4 & 4 & 3 & 1 & 4 \\
\hline Lithuania & 2 & 4 & 4 & 4 & 2 & 4 & 3 & 4 & 3 & 1 & 4 & 4 & 4 & 4 & 3 & 1 & 1 \\
\hline Latvia & 2 & 4 & 4 & 4 & 4 & 4 & 3 & 4 & 2 & 1 & 2 & 4 & 4 & 4 & 3 & 1 & 2 \\
\hline Malta & 3 & 1 & 3 & 3 & 1 & 2 & 1 & 2 & 2 & 4 & 4 & 2 & 3 & 4 & 4 & 4 & 4 \\
\hline Poland & 1 & 2 & 3 & 2 & 4 & 2 & 1 & 3 & 3 & 4 & 4 & 4 & 4 & 2 & 2 & 3 & 2 \\
\hline Romania & 1 & 4 & 3 & 4 & 4 & 2 & 4 & 4 & 4 & 3 & 2 & 3 & 4 & 3 & 3 & 3 & 4 \\
\hline Slovakia & 1 & 3 & 3 & 3 & 3 & 4 & 3 & 4 & 4 & 3 & 4 & 2 & 3 & 3 & 3 & 2 & 2 \\
\hline Slovenia & 1 & 2 & 3 & 2 & 3 & 2 & 1 & 2 & 3 & 2 & 2 & 2 & 2 & 2 & 3 & 2 & 3 \\
\hline Hungary & 3 & 4 & 4 & 3 & 1 & 2 & 1 & 1 & 3 & 4 & 3 & 3 & 2 & 4 & 3 & 2 & 1 \\
\hline
\end{tabular}

Source: own calculations.

In the groups characterized by strong economic growth, the new members of the European Union (mainly the Baltic Sea countries), Ireland and Luxembourg were the main players. All the models obtained were characterized by high or very high quality of classification (see Table 4).

Table 4. Quality of discriminant analysis in 2000-2016

\begin{tabular}{|c|c|c|}
\hline Year & Wilks' Lambda & Accuracy of classification (\%) \\
\hline 2000 & 0.019 & 95.65 \\
\hline 2001 & 0.060 & 84.00 \\
\hline 2002 & 0.055 & 96.30 \\
\hline 2003 & 0.009 & 100.00 \\
\hline 2004 & 0.060 & 92.59 \\
\hline 2005 & 0.004 & 96.30 \\
\hline 2006 & 0.047 & 92.59 \\
\hline 2007 & 0.020 & 96.30 \\
\hline 2008 & 0.036 & 96.30 \\
\hline 2009 & 0.022 & 88.89 \\
\hline 2010 & 0.077 & 77.78 \\
\hline 2011 & 0.029 & 100.00 \\
\hline 2012 & 0.021 & 96.30 \\
\hline 2013 & 0.069 & 88.89 \\
\hline 2014 & 0.016 & 100.00 \\
\hline 2015 & 0.014 & 85.19 \\
\hline 2016 & 0.039 & 85.19 \\
\hline
\end{tabular}

Source: own calculations. 
Table 5 presents the factors that determined the economic growth of EU countries in particular years. The key factors were selected on the basis of their contribution to discrimination assessed on the basis of the standardized values of the first discriminant function, which corresponded to the highest eigenvalue.

Table 5. Key factors of economic growth of EU countries in 2000-2016

\begin{tabular}{|c|c|c|c|c|c|c|c|c|c|c|c|c|c|c|c|c|c|c|}
\hline Variables & 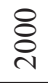 & ᄅ্ণ & ণิ & 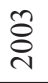 & $\underset{\sim}{\stackrel{+}{~}}$ & ڤి & ¿̊ & $\widehat{\stackrel{8}{\circ}}$ & 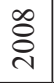 & ஓे & $\stackrel{\circ}{\stackrel{\circ}{\sim}}$ & $\vec{\sim}$ & $\frac{\sim}{\stackrel{\sim}{\sim}}$ & $\stackrel{m}{\stackrel{d}{d}}$ & $\underset{\sim}{\stackrel{\sim}{\sim}}$ & $\frac{n}{\stackrel{n}{c}}$ & $\stackrel{0}{\stackrel{0}{\circ}}$ & $N$ \\
\hline$X_{1}$ & $\bullet$ & $\bullet$ & & & & & & & & $\bullet$ & & & & & & & & 3 \\
\hline$X_{2}$ & & & & & $\bullet$ & $\bullet$ & & & $\bullet$ & & & & & $\bullet$ & & & & 4 \\
\hline $\mathrm{X}_{3}$ & & & & $\bullet$ & & $\cdot$ & $\bullet$ & $\bullet$ & & & $\bullet$ & & $\bullet$ & & $\bullet$ & $\bullet$ & $\bullet$ & 9 \\
\hline $\mathrm{X}_{4}$ & $\bullet$ & $\bullet$ & & $\bullet$ & & $\bullet$ & $\bullet$ & & $\bullet$ & $\bullet$ & $\bullet$ & $\bullet$ & $\bullet$ & $\bullet$ & $\bullet$ & $\bullet$ & & 13 \\
\hline$X_{5}$ & & & & & $\bullet$ & & & & & & & & & & $\bullet$ & & $\bullet$ & 3 \\
\hline$X_{6}$ & & & & $\bullet$ & & & & & & $\bullet$ & & & $\bullet$ & $\bullet$ & & & & 4 \\
\hline $\mathrm{X}_{7}$ & & & $\bullet$ & & $\bullet$ & & & & & & & & & & $\bullet$ & $\bullet$ & & 4 \\
\hline $\mathrm{X}_{8}$ & $\bullet$ & $\bullet$ & $\bullet$ & $\bullet$ & $\bullet$ & $\bullet$ & $\bullet$ & $\bullet$ & $\bullet$ & $\bullet$ & $\bullet$ & $\bullet$ & $\bullet$ & $\bullet$ & & & & 14 \\
\hline$X_{9}$ & $\bullet$ & & & & & & & $\bullet$ & & & $\bullet$ & $\bullet$ & $\bullet$ & & $\bullet$ & $\bullet$ & & 7 \\
\hline$X_{10}$ & $\bullet$ & & & $\bullet$ & & & & & & & & & & & & & & 2 \\
\hline$X_{11}$ & $\bullet$ & & $\bullet$ & & $\bullet$ & & $\bullet$ & & $\bullet$ & & & $\bullet$ & & & $\bullet$ & $\bullet$ & $\bullet$ & 9 \\
\hline$X_{12}$ & & $\bullet$ & & & & & & $\bullet$ & & & $\bullet$ & & & & $\bullet$ & & & 4 \\
\hline
\end{tabular}

Source: own calculations.

The most important growth determinants were: consumption (during 14 years), investment (13 years), export ( 9 years) and labour productivity ( 7 years). The impact of consumption on GDP dynamics has been stressed many times by the national statistical offices and Eurostat, therefore the significant impact of investment on the economic growth dynamics is not surprising. This is not only consistent with the theory of economics, but is also confirmed by many previous studies [Ismail, Ahmed 2015]. The results obtained suggest that for almost the last twenty years we have observed in the EU consumption and investment-driven economic growth. It can also be observed that the impact of export has been strongest during the three consecutive years following the enlargement of the European Union and in recent years. In the former case this was probably due to the availability of new markets and the removal of the existing restrictions on international trade. In the latter, however, export became a specific substitute for internal consumption. An interesting regularity can also be observed in the years of the economic slowdown of 2001 and 2009, in which the diversity of GDP growth in the EU countries was associated with the strong impact of public debt. 


\section{Conclusions}

When interpreting the results, it should be borne in mind that this study took into account only selected potential growth factors, mainly of an economic nature, omitting such phenomena as income inequalities, employee mobility, the level of human capital and the level of social trust. In future studies it would also be useful to take into account factors that enable to verify whether we are dealing with innovation-driven growth when the rate of economic growth depends on the level of innovation in the economy. However this does not change the fact that the process of generating domestic product in the EU countries in 2010-2016 was dominated by classic growth factors such as consumption, investment, export and labour productivity. The enlargement of the European Union and the decrease in consumption caused an increase in the importance of export as an essential factor of growth. During the last twenty years or so, the countries with the lowest economic growth rate included the old EU countries (Denmark, Greece, the Netherlands, Portugal and Italy), while the countries with the highest economic growth rate included new members of the EU (Estonia, Lithuania, Latvia and Romania). In the countries with the least resilience to the effects of the economic crisis, we noticed that public debt increased, employment, investment, consumption and export declined, while at the same time migration increased. From the point of view of economic policy making, an important conclusion is that all the factors characterising resources, quality and costs of labour and government expenditure do not affect economic growth in a substantial way.

Further research on the key determinants of economic growth should not only concern the enlarged set of countries, but also take into account the differences in the level of development of individual countries. This would make it possible to verify the hypothesis that countries with different levels of development are characterized by different patterns of economic growth. It would also be worth to analyze the sensitivity of the obtained results to the application of other research methods.

\section{Bibliography}

Agrawal K., Maheshwari J., 2014, Default risk modelling using macroeconomic variables, Journal of Indian Business Research, vol. 6, no. 4, pp. 270-285.

Ahn S., Hemmings P., 2000, Policy Influences on Economic Growth in OECD Countries: An Evaluation of the Evidence, OECD, Economics Department, Economics Department Working Papers, no. 246, OECD, Paris.

Barro R.J., 1996, Determinants Of Economic Growth: A Cross-Country Empirical Study, NBER Working Paper 5698, Cambridge.

Batóg J., 2007, Próba klasyfikacji czynników wzrostu gospodarczego, Metody ilościowe w ekonomii, Zeszyty Naukowe Uniwersytetu Szczecińskiego, no. 450, Prace Katedry Ekonometrii i Statystyki no. 17 , pp. 43-56. 
Batóg J., 2009, Wykorzystanie analizy dyskryminacyjnej z autokorelacja przestrzenna do klasyfikacji obiektów, Prace Naukowe Uniwersytetu Ekonomicznego we Wrocławiu, no. 47, Taksonomia 16, Klasyfikacja i analiza danych - teoria i zastosowania, pp. 382-389.

Batóg B., Batóg J., 2012, Wykorzystanie analizy dyskryminacyjnej do identyfikacji czynników determinujacych stope zwrotu z inwestycji na rynku kapitałowym, Prace Naukowe Uniwersytetu Ekonomicznego we Wrocławiu, Taksonomia 19. Klasyfikacja i analiza danych - teoria i zastosowania, no. 242, pp. 387-395.

Batóg J., 2010, Konwergencja dochodowa w krajach Unii Europejskiej. Analiza ekonometryczna, Uniwersytet Szczeciński, Rozprawy i Studia T. (DCCCLIV) 780, Wydawnictwo Naukowe Uniwersytetu Szczecińskiego, Szczecin.

Batóg B., Wawrzyniak K., 1997, Wykorzystanie funkcji dyskryminacyjnej do oceny kondycji finansowo-ekonomicznej spótek i przedsiębiorstw I, II, III i IV transzy alokowanych do Narodowych Funduszy Inwestycyjnych, Przegląd Statystyczny, vol. 44, no. 1, pp. 105-115.

Borys T., 2005, Indicators for Sustainable Development - Polish Experiences, Wydawnictwo Ekonomia i Środowisko, Warszawa - Białystok.

Bosworth B., Collins S.M., 2003, The Empirics of Growth: An Update, Brookings Papers on Economic Activity, no. 2, pp. 113-206, DOI: 10.1353/eca.2004.0002.

Budner W.W., 2006, Zmiany zależności ekonomicznych polskiej gospodarki w okresie transformacji $w$ wymiarze regionalnym, Prace Habilitacyjne, no. 27, Wydawnictwo Akademii Ekonomicznej w Poznaniu, Poznań.

Choudhury A.H., Naidu G.N., 2009, Turkey's Economic Integration with the EU: An Evaluation of Current Status and Future Prognosis, Journal of International Business Research, vol. 8, no. 1, pp. 29-43.

Cortés E.A., Navarro J.L.A., 2011, Do ICT Influence Economic Growth and Human Development in European Union Countries?, International Advances in Economic Research, vol. 17, no. 1, pp. 28-44, DOI: 10.1007/s11294-010-9289-5.

Czerwiński Z., 2002, Stopa inwestycji a maksymalizacja spożycia, [in:] Moje zmagania z ekonomia, Wydawnictwo Akademii Ekonomicznej w Poznaniu, Poznań.

Doppelhoffer G., 2000, Three Essays on the Determinants of Economic Growth, unpublished Ph.D. dissertation, Columbia University.

Doppelhofer G., Miller R. I., Sala-i-Martin X., 2000, Determinants of Long-term Growth: A Bayesian Averaging of Classical Estimates (BACE) Approach, Economics Department Working Papers no. 266, OECD, Paris.

Durlauf S.N., Johnson P.A., Temple J.R.W., 2005, Growth Econometrics, [in:] P. Aghion, S.N. Durlauf (eds.), Handbook of Economic Growth, Vol. 1A, Handbooks in Economics 22, Elsevier, North-Holland.

Fernandes S., 2013, An empirical approach of the distinctive aspects for socioeconomic development, International Journal of Social Economics, vol. 40, no. 11, pp. 956-970, DOI: 10.1108/IJSE-022012-0031.

Fisher R.A., 1936, The use of multiple measurements in taxonomic problems, Annals of Eugenics, vol. 7, no. 2, pp. 179-188.

Ismail S., Ahmed S., 2015, Economic growth and macro variables in India: An empirical study, Journal of Economics and Development, vol.17, no. 3, December, pp. 42-59.

Johnson R.A., Wichern D.W., 2007, Applied Multivariate Statistical Analysis, Pearson Education.

Kosikowski C., 2004, Potrzeba i możliwości wspierania dtugookresowego wzrostu gospodarczego i dynamicznego rozwoju gospodarczego Polski przez prawo, [in:] G. Kołodko (ed.), Strategia szybkiego wzrostu gospodarczego w Polsce, Wydawnictwo Wyższej Szkoły Przedsiębiorczości i Zarządzania im. Leona Koźmińskiego, Warszawa, pp. 163-176.

Maniatis P., 2013, The place of the eurozone countries in the international economy. Comparison using discriminant analysis, Journal of Economic Studies, vol. 40, no. 2, pp. 127-179, DOI: $10.1108 / 01443581311283655$. 
McLachlan G.J., 2004, Discriminant Analysis and Statistical Pattern Recognition, John Wiley \& Sons. Panek T., 2009, Metody statystyczne wielowymiarowej analizy porównawczej, Szkoła Główna Handlowa w Warszawie, Warszawa.

Piasecki R., 2003, Rozwój gospodarczy a globalizacja, PWE, Warszawa.

Piontek B., 2006, Współczesne uwarunkowania rozwoju społeczno-gospodarczego, Rozprawy Naukowe, no. 13, Wydawnictwo Akademii Techniczno-Humanistycznej w Bielsku-Białej, Bielsko-Biała.

Pociecha J., 2007, Problemy prognozowania bankructwa firmy metoda analizy dyskryminacyjnej, Unifikacja programów nauczania przedmiotów ilościowych, Acta Universitatis Lodziensis. Folia Oeconomica, no. 205, pp. 63-79.

Pritchett L., 2000, Understanding patterns of economic growth: searching for Hills among Plateaus, mountains, and plains, The World Bank Economic Review, May, vol. 14, no. 2, pp. 221-250.

Próchniak M., 2005, Bariery wzrostu gospodarczego. Przeglad wyników badań empirycznych, Zeszyty Naukowe, Szkoła Główna Handlowa, Kolegium Gospodarki Światowej, no. 17, pp. 76-101.

Rapacki R. (ed.), 2009, Wzrost gospodarczy w krajach transformacji: konwergencja czy dywergencja?, PWE, Warszawa.

Rapacki R., Próchniak M., 2014, Wpływ członkostwa w Unii Europejskiej na wzrost gospodarczy i realna konwergencję krajów Europy Środkowo-Wschodniej, Ekonomia, no. 39, pp. 87-122.

Siedlecki J., 2000, Równowaga a wzrost gospodarczy, Wydawnictwo Naukowe PWN, Warszawa-Wrocław.

Tacq J., 2007, Multivariate Analysis in Social Science Research, Sage Publications, London.

Temple J., 1999, The new growth evidence, Journal of Economic Literature, vol. 37, no. 1, pp. 112-156.

Trpkova M., Tevdovski D., 2010, Applied discriminant analysis in the estimation of potential EU members, Revista Tinerilor Economişti (The Young Economists Journal), vol. 1, issue 15, pp. 135-147.

Woźniak G.M., 2004, Wzrost gospodarczy. Podstawy teoretyczne, Wydawnictwo Akademii Ekonomicznej w Krakowie, Kraków.

Zrozumieć wzrost gospodarczy. Analiza na poziomie makroekonomicznym, poziomie branży i poziomie firmy, 2005, OECD, Oficyna Ekonomiczna, Kraków.

\title{
MAKROEKONOMICZNE CZYNNIKI WZROSTU GOSPODARCZEGO W UNII EUROPEJSKIEJ W LATACH 2000-2016: ANALIZA WIELOWYMIAROWA
}

\begin{abstract}
Streszczenie: Konstrukcja efektywnej polityki w obszarze wzrostu gospodarczego wymaga identyfikacji jego kluczowych determinant. W przeprowadzonym badaniu wykorzystano jedną z metod analizy wielowymiarowej - analizę dyskryminacyjną. Jest ona szeroko stosowana w skali mikroekonomicznej, zwłaszcza w obszarze przewidywania bankructwa przedsiębiorstw, jednak w zagadnieniu wzrostu gospodarczego nie była praktycznie dotychczas wykorzystywana. Oprócz głównego celu polegającego na wskazaniu najważniejszych czynników wzrostu gospodarczego krajów Unii Europejskiej w latach 2000-2016, badany był wpływ kryzysu oraz akcesji do UE. Źródłem danych statystycznych były bazy Eurostat oraz The Conference Board (Total Economy Database). Uzyskane wyniki pozwoliły stwierdzić, że o stopie wzrostu PKB krajów UE decydowały: konsumpcja, inwestycje, eksport i wydajność pracy, a w okresach spowolnienia gospodarczego również dług publiczny. Przystąpienie do UE powodowało wzrost znaczenia eksportu.
\end{abstract}

Słowa kluczowe: wzrost gospodarczy, analiza dyskryminacyjna, Unia Europejska, kryzys gospodarczy. 